\title{
SEASONAL VARIATION AND FOOD DEPRIVATION IN COMMON VAMPIRE BATS (CHIROPTERA: PHYLLOSTOMIDAE)
}

\author{
FREITAS, M. B., WELKER, A. F. and PINHEIRO, E. C. \\ Department of Physiological Sciences (CFS), University of Brasilia - UnB, Institute of Biological Sciences - IB, \\ Campus Universitário, Asa Norte, CEP 70910900, Brasília, DF, Brazil \\ Correspondence to: Mariella Bontempo Duca de Freitas, Department of Physiological Sciences (CFS), \\ University of Brasilia - UnB, Institute of Biological Sciences - IB, Campus Universitário, Asa Norte, \\ CEP 70910900, Brasília, DF, Brazil, e-mail: mariella@unb.br \\ Received August 18, 2004 - Accepted December 20, 2004 - Distributed November 1, 2006
}

(With 1 figure)

\begin{abstract}
The aim of this study was to investigate the effects of seasonal variation and fasting on fat reserves of the common vampire bat Desmodus rotundus. Plasma free fatty acids (FFA), along with lipid content of the liver and muscles, and fatty acids from the carcass were obtained from bats fed bovine blood and from whom food was subsequently withheld for 24 and $48 \mathrm{~h}$. Animals were caught during both dry and rainy seasons. In general, fat tissue stores were not significantly influenced by seasonal variation. Lipid content of liver, muscles, and carcass decreased during some food deprivation periods, although the concomitant increase expected in plasma FFA was not observed. Lipid metabolism is hypothesized as being continued by the tissues themselves. In addition, free access to food sources (e.g., domestic livestock) throughout the year is believed to contribute to the low seasonal variations in fat reserves observed in the common vampire bat.
\end{abstract}

Keywords: seasons, food deprivation, lipids, metabolism, Desmodus rotundus.

\section{RESUMO}

\section{Efeitos do jejum e da variação sazonal sobre as reservas lipídicas de morcegos hematófagos (Chiroptera: Phyllostomidae)}

Os efeitos da variação sazonal e do jejum sobre as reservas lipídicas do morcego vampiro comum (Desmodus rotundus) foram investigadas a fim de se estabelecer o padrão do metabolismo de lipídios da espécie e possíveis alterações sazonais. Foram determinadas as concentrações de Ácidos Graxos Livres (AGL) e o conteúdo lipídico no fígado, músculos e na carcaça de animais alimentados (sangue bovino) e jejuados por 24 e 48 h, capturados durante as estações seca e chuvosa. Em geral, os depósitos lipídicos teciduais não apresentaram variações significativas em resposta às diferentes estações. As reservas de gordura diminuíram, no entanto, em resposta ao jejum, apesar de não ter sido observado nenhum aumento simultâneo dos AGL no plasma, aumento que normalmente indica mobilização lipídica. O metabolismo lipídico nestes tecidos parece importante para as necessidades energéticas dos próprios tecidos. Fatores como abundância e facilidade de acesso às presas (bovinos) podem estar contribuindo para a baixa variabilidade sazonal das reservas lipídicas teciduais.

Palavras-chave: variação sazonal, jejum, metabolismo, lipídios, Desmodus rotundus.

\section{INTRODUCTION}

As they seem to constitute the main nutrient source during flight, lipid stores in various bat species have been the focus of many studies (George \& Jyoti, 1955; Okon et al., 1978). Besides lipids, other energy sources, e.g., glycogen and proteins, are also used by bats and other animals (Freitas et al., 2003). However, studies on the enzyme profile of bats have reported that, in numerous species, including the neotropical phyllostomids, 
breast muscles present higher activity of lipid metabolic enzymes (Yacoe et al., 1982).

Several factors can influence fat storage. According to McNab (1976), fat reserves found in bats appears to be related to their feeding habits. Thus, nectarivorous species demonstrated significantly smaller fat-reserve levels throughout the year, whereas insectivorous bats showed greater annual variation, when compared to animals with different feeding habits (McNab, 1976). In addition, environmental conditions, seasonal variations, and sexual dimorphism have also been reported to cause variations in fat deposits of bats. In the Phyllostomidae family, several species specialized on eating insects, fruit, and nectar have shown a significant decrease in fat stores during the dry season when food availability decreases (McNab, 1976).

Studies on fat reserves in vampire bats, however, are still few, although these animals are of particular interest mainly because they are sanguivorous, which is the case of the common vampire bat (Desmodus rotundus), which generally inhabits caves near domestic livestock (Delpietro et al., 1993), a plentiful prey (Turner, 1975). Although this species is typically regarded as polyestrous year-round, studies on its reproduction in tropical zones have indicated a marked preference for spring-summer (the rainy season) (Nunes \& De Viana, 1997). However, this pattern may have resulted from environmental conditions (e.g., temperature, humidity) instead of food availability (Nuñes \& De Viana, 1997).

Previous studies in our laboratory have demonstrated that the common vampire bat is highly susceptible to the effects of absolute food deprivation since they store less energy reserves than most mammals (Freitas et al., 2003), but influence of the marked dry and rainy seasons of central Brazil on their intermediate metabolism and responses to food deprivation have not yet been investigated.

This study focuses on variations in fat reserves of the common vampire bat in response to seasonal variations (i.e., dry and rainy seasons) and food shortages. Plasma free fatty acids, fat concentrations in muscles and liver, and fatty acids in the carcass were determined in adult male and female bats caught during both dry and rainy seasons, fed, and fasted for 24 and $48 \mathrm{~h}$.

\section{MATERIAL AND METHODS}

\section{Study area}

The study, conducted in cooperation with the Institute of Health of the Federal District/Zoonose Center for Animal Management and Control, was carried out north of Brasilia, DF (Federal District). Located in central Brazil, this area has two clearly defined seasons: the dry (April- September) and the rainy (October-March).

To identify rabies virus, The Zoonosis Center periodically catches $D$. rotundus to verify possible occurrence of rabies virus, and bat tissues used in the present study were from the same individuals used by the Center.

Animals- Thirty-eight male and 42 nonpregnant female adult bats (Desmodus rotundus) $(22-40 \mathrm{~g})$ were analyzed. Bats were caught by mist nets during both dry and rainy seasons. They were taken to the laboratory and maintained in the dark, at room temperature, in wire mesh cages. To minimize agonistic behaviors they were housed in same-sex groups, each having 4 individuals.

All bats were initially fed bovine blood obtained from healthy cows and defribrinated in containers with glass pearls after manual agitation. At 19 h 30$40 \mathrm{~mL}$ of bovine blood per subject was offered in petri dishes, which were removed next morning at $7 \mathrm{~h}$. Blood and water were available ad libitum for all animals on two consecutive nights following capture. Experimental groups were also fasted for 24 or $48 \mathrm{~h}$, during which only water was available.

\section{Experimental procedures}

Plasma free fatty acid (FFA) levels, fat concentrations in the liver and muscles (breast and limbs), and fatty acids in the carcass were determined in fed, 24 (F24), and $48 \mathrm{~h}$ (F48) fasted bats captured during dry and rainy seasons. The FFA levels were determined directly on plasma aliquots, using the method of Dole and Meinertz (1960). Total lipid concentrations in muscles and liver were determined gravimetrically from tissues homogenized in a chloroform-methanol (2:1) solution, according to Folch et al. (1957). Fatty acids were determined after removing tissue from a section of the gastro-intestinal tract extending from the terminal esophageal segment to the anus. The carcass was completely digested in $100 \mathrm{~mL}$ $\mathrm{KOH} 6 \mathrm{~N}$, filtered and added to the same volume 
of absolute alcohol, yielding a $50 \%(\mathrm{v} / \mathrm{v}) \mathrm{KOH}-$ ethanol solution. After extraction with chloroform, fatty acids were determined gravimetrically.

Statistical analysis- Results are presented \pm SEM. Using two-way ANOVA followed by the Tukey test, data were analyzed for differences between nutritional conditions in the dry and in the rainy seasons. Criterion for rejection in all tests was $\mathrm{P}<0.05$.

\section{RESULTS}

\section{Plasma FFA}

Plasma FFA levels did not differ significantly in vampire bats captured in the dry and rainy seasons. A significant decrease $(\mathrm{P}<0.05)$ in this parameter was observed only in response to fasting, when F-48 bats captured during the rainy season showed decreased plasma FFA levels when compared to nonfasted bats caught during the same season (Fig. 1).

\section{Breast and limb muscle lipid content}

Significant differences in muscle lipid content were not observed in bats captured during the dry and rainy seasons. Following fasting, this content in muscles of both groups was unaltered (Table 1).

\section{Liver lipid content and carcass fatty acids}

Liver lipid concentrations showed no significant seasonal differences, nor did these concentrations change in response to experimental fasting periods. In addition, fatty acids of the carcass presented similar values in bats captured during both dry and rainy seasons. However, these concentrations fell $(\mathrm{P}<0.05)$ in $48 \mathrm{~h}$ fasted bats caught in both seasons (Table 2).

\section{DISCUSSION}

Seasonal variations in body fat reserves, found in numerous temperate-zone bats (Arévalo et al., 1990), have also been reported in certain tropical species (McNab, 1976). In neotropical bats,

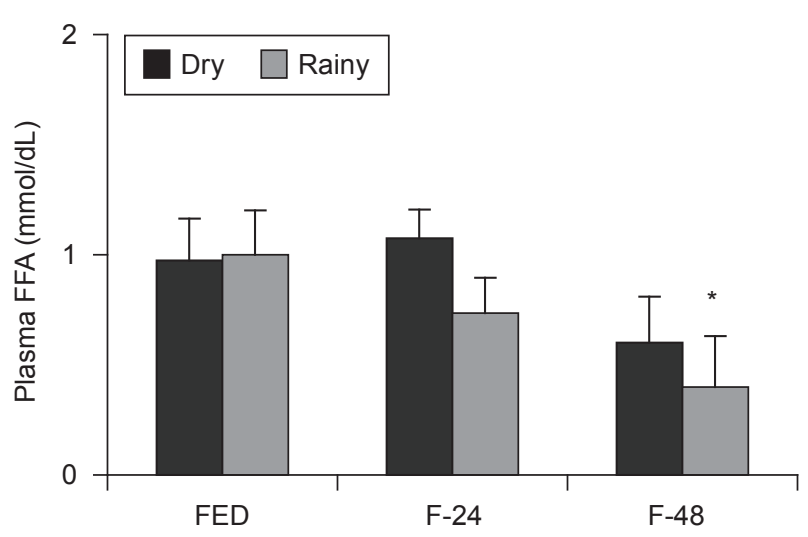

Fig. 1 - Changes in plasma free fatty acids (FFA; $\mu \mathrm{mol} / \mathrm{dL}$ ) of fed (FED), 24 h-fasted (F-24) and 48-h fasted (F-48) vampire bats. Values are presented as the mean \pm SEM of $4-12$ individuals per group. $* \mathrm{P}<0.05 v s$. fed animals caught during the rainy season.

TABLE 1

Breast and limb muscle fat concentrations (g/100 g wet wt) in fed (FED), $24 \mathrm{~h}$ fasted (F-24), and 48-h fasted (F-48) vampire bats caught during the dry and rainy seasons. Values are presented as the mean \pm SEM.

The number of individuals appears in parentheses.

\begin{tabular}{|c|c|c|c|c|}
\hline & \multicolumn{2}{|c|}{ Dry season } & \multicolumn{2}{c|}{ Rainy season } \\
\hline & Breast & Limbs & Breast & Limbs \\
\hline FED & $7.89 \pm 0.67(12)$ & $3.32 \pm 0.32(12)$ & $6.84 \pm 0.53(12)$ & $3.04 \pm 0.24(10)$ \\
\hline F-24 & $7.09 \pm 0.27(12)$ & $3.15 \pm 0.49(11)$ & $6.43 \pm 0.81(11)$ & $2.69 \pm 0.45(11)$ \\
\hline F-48 & $7.67 \pm 0.79(12)$ & $3.07 \pm 0.28(10)$ & $6.00 \pm 0.76(12)$ & $3.59 \pm 0.22(10)$ \\
\hline
\end{tabular}


TABLE 2

Liver fat concentrations (g/100 g) and carcass fatty acids $(\mu \mathrm{mol} / \mathrm{dL})$ of carcass in fed (FED), and 24-h (F-24) and 48-h fasted (F-48) vampire bats captured during the dry and rainy seasons. Values represent the mean \pm SEM. The number of animals are given in parentheses. $* \mathrm{P}<0.05 v s$. fed animals captured in the same season.

\begin{tabular}{|l|c|c|c|c|}
\hline & \multicolumn{2}{|c|}{ Dry season } & \multicolumn{2}{c|}{ Rainy season } \\
\hline & Liver & Carcass & Liver & Carcass \\
\hline FED & $5.58 \pm 0.6(12)$ & $4.85 \pm 0.92(12)$ & $5.25 \pm 0.44(11)$ & $4.13 \pm 0.59(13)$ \\
\hline F-24 & $4.71 \pm 0.66(10)$ & $3.24 \pm 0.89(10)$ & $4.46 \pm 0.82(12)$ & $3.18 \pm 0.66(11)$ \\
\hline F-48 & $4.94 \pm 0.89(10)$ & $\mathbf{2 . 1 1} \pm \mathbf{0 . 2 3} *(\mathbf{1 0})$ & $5.35 \pm 0.49(9)$ & $\mathbf{1 . 7 5} \pm \mathbf{0 . 1 4}(\mathbf{9})$ \\
\hline
\end{tabular}

seasonal differences in fat reserves are thought to be influenced by feeding behavior (McNab, 1976). Accordingly, insectivorous species demonstrated greater annual variations relative to bats with other feeding habits (frugivorous, nectarivorous, and polinivorous). From the eight species studied by McNab (1976), year-round stability in fat stores was observed only in Monophyllus redmani, a nectarivorous species.

In the present study, analyses of fed vampire bats (Desmodus rotundus) revealed low lipid concentrations in animals caught during both seasons, as well as total absence of abdominal fat reserves. However, in fed fruit-eating bats (Artibeus lituratus and A. jamaicensis), Pinheiro (1995) observed large amounts of abdominal fat deposits, which markedly decreased in response to fasting. In vampire bats, only prolonged periods of fasting (i.e., $48 \mathrm{~h}$ ) induced occasional variations in muscle lipid stores, which were observed sporadically in some of the analyzed tissues. In general, season variations did not influence fat reserves in vampire bats submitted to 24 and $48 \mathrm{~h}$ of food deprivation. Lipid content in the liver and muscles of fasted D. rotundus varied considerably in both seasons, but showed no specific pattern or tendency. Since the food resource (domestic livestock) is available year-round, it can be ruled out as a factor in lipid reserve alterations in these animals.

Curiously, occasional decreases of fat reserves in D. rotundus were not followed by an increase in plasma FFA, which actually decreased in response to food deprivation.

It is widely known that in the majority of vertebrates most fat-store breakdowns contribute to energy homeostasis by supplying FFA for muscle contraction and glycerol for liver gluconeogenesis (Kraus-Friedmann, 1984). However, the present study suggests that these reserves may be important only for supplying the tissue itself, as observed by Yacoe et al.(1982) in other bat species, and would probably depend on prolonged fasting conditions (i.e., 48 h). But under normal conditions, D. rotundus seems unable to store/mobilize large quantities of fat.

Small amounts of lipids in specific tissues have also been observed in meadow voles (Microtus pennsylvanicus)(Nagy \& Pistole, 1988) and in red and red-gray voles (Mosin, 1982, 1984). These gramnivorous and omnivorous rodents rely almost exclusively on carbohydrates for fuel sources, in spite of which during fasting significant mobilization of body fat was not observed (Nagy \& Pistole, 1988). Similarly to what was found in our study, lipid stores in voles remained stable in most tissues until $72 \mathrm{~h}$ of food deprivation. Nevertheless, most mammals so far been investigated use lipids as their main fuel source in times of shortage (Okon et al., 1978).

A further factor in energy metabolism is environmental temperature. Apparently, vampire bats are poor thermoregulators, and maintaining body temperature in cold environments requires heavy increments in energy expenditure (McNab, 1973). In central Brazil, during the dry season, night temperatures are lower than those of the rainy season, which could result in increased oxygen consumption so as to elevate this species' body temperature during flight (Cruz-Neto, 1998). In addition, the possibility that lipids are an energy source under these circumstances should not be discarded. As vampire bats have been shown to be highly susceptible to the effects of food deprivation since they store less energy reserves than most mammals (Freitas et al., 2003), it seems probable that they depend on year-round food availability. 
In conclusion, our results indicate that fat reserves of $D$. rotundus do not vary consistently either in response to seasonal variations or to food deprivation. Only more prolonged periods of fasting result in decreased fat content and, even so, only in some of the studied tissues. However, this fat mobilization seems to be for supplying tissue, since glucose levels in the bloodstream remain low. This minimal dependence on lipid stores to elevate blood glucose in these animals may be due to (1) limited capacity to store energy fuel as fat in different tissues when food is available, and/or (2) inadequate capacity to mobilize lipid stores during periods of food shortage. Both reasons may be a consequence of the usually constant availability of food resources throughout the year, associated with the food sharing behavior frequently observed among common vampire bats (Wilkinson, 1990).

Acknowledgments - We thank A. Bredt and E. Magalhães for providing field assistance, J. Diogo for supplying bovine blood, I. Kettelhut and A. Garofalo for determining plasma FFA, M. Barros for reviewing this manuscript, and CAPES and FAP-DF for financial support.

\section{REFERENCES}

ARÉVALO, F., BURGOS, M. J., DEL HOYO, N. \& LÓPEZLUNA, P., 1990, Seasonal variations in the lipid composition of white and brown tissues in the bat Pipistrellus pipistrellus. Comp. Biochem. Physiol., 95B(3): 535-539.

BREDT, A., UIEDA, W. \& MAGALHÃES, E., 1999, Morcegos cavernícolas da região do Distrito Federal, centro-oeste do Brasil (Mammalia, Chiroptera). Ver. Bras. Zool., 16(3): 731-770.

CRUZ-NETO, A. P., 1998, Homeostase térmica e energética em morcegos da Família Phyllostomidae. Ph. D. dissertation, São Paulo State University, Rio Claro, São Paulo, Brasil.

DELPIETRO, H. A., MARCHEVSKY, N. \& SIMONETTI, 1993, Relative population densities and predation of the common vampire bat (Desmodus rotundus) in natural and cattle-raising areas in north-east Argentina. Prev. Vet. Med., 14: 13 .

DOLE, V. P. \& MEINERTZ, H., 1960, Microdetermination of long-chain fatty acids in plasma and tissues. J. Biol. Chem., 235: 2595-2599.
FOLCH, J., LESS, M. \& SLOANE-STANLEY, G. H., 1957, A simple method for the isolation and purification of total lipids from animal tissues. J. Biol. Chem., 226: 497.

FREITAS, M. B., WELKER, A. F., MILLAN, S. F., PINHEIRO, E. C., 2003, Metabolic responses induced by fasting in the common vampire bat (Desmodus rotundus). J. Comp. Physiol., (B) 173(8): 703-707.

GEORGE, J. C. \& JYOTI, D., 1955, Histological features of the breast and leg muscles of bird and bat and their physiological and evolutionary significance. J. Anim. Morph. Physiol., 2: 31-36.

KRAUS-FRIEDMANN, N., 1984, Hormonal regulation of hepatic gluconeogenesis. Physiol. Rev., 64(1): 170-220.

McNAB, B. K., 1973, Energetics and the distribution of vampires. J. Mammal., 54(1): 131.

McNAB, B. K., 1976, Seasonal fat reserves in two tropical environments. Ecology, 57: 332-338.

MOSIN, A. F., 1982, Some physiological and biochemical features of starvation and refeeding in small wild rodents (Microtinae). Comp. Biochem. Physiol., 71A: 461-464.

MOSIN, A. F., 1984, On the energy fuel in voles during their starvation. Comp. Biochem. Physiol., 77A(3): 563-565.

NAGY, T. R. \& PISTOLE, D. H., 1988, The effects of fasting on some physiological parameters in the meadow vole, Microtus pennsylvanicus. Comp. Biochem. Physiol., 91A(4): 679-684.

NUÑEZ, H. A. \& VIANNA M. L.. 1997. Estacionalidad reproductiva en el vampiro común Desmodus rotundus en el Valle de Lerma (Salta, Argentina). Revista de Biologia Tropical, Salta, 45(3): 1231-1235.

OKON, E. E., UMUKORO, R. M. \& AJUDUA, A., 1978, Diurnal variations of the glycogen and fat stores in the liver and the breast muscle of the fruit bat, Eidolon helvum (Kerr). Physiol. Behav., 20: 121-123.

PINHEIRO, E. C., 1995, Metabolismo intermediário de morcegos frugívoros. Ph. D. dissertation, University of São Paulo, São Paulo, Brasil.

TURNER, D. C., 1975, The vampire bat: A field study in behavior and ecology. $1^{\circ}$ vol. 144p. John Hopkins University Press, Baltimore.

YACOE, M. E., CUMMINGS, J. W., MYERS, P. \& CREIGHTON, K., 1982, Muscle enzyme profile, diet, and flight in South American bats. Am. J. Physiol., 11: R189R194.

WILKINSON, G. S., 1990, Food sharing in vampire bats. Sci. Amer. 262(2): 76. 
